\title{
Türkiye’de Batı Karadeniz bölgesindeki çocukların D vitamini düzeyleri
}

\author{
Vitamin D levels of children in Western Black Sea region of Turkey
}

Erkan Doğan, Nergiz Sevinç

Gönderilme tarihi:12.04.2020

Kabul tarihi:24.07.2020

\begin{abstract}
Özet
Amaç: D vitamin seviyesi, güneş ışınlarının cilt yüzeyine temas açısına ve süresine, besinler ile alınan miktarına ve de oral yolla destek amaçlı alım miktarına göre kişisel farklılıklar gösterir. Beslenme alışkanlıklarının yanında yerleşim merkezlerinin konumu, denizden yükseklikleri ve iklim özelikleri bireylerin serum 25(OH) D vitamin düzeylerini etkilemektedir. Bu çalışmada, Batı Karadeniz bölgesindeki çocukların serum 25(OH) D vitamin düzeylerini tespit etmek amaçlandı.

Gereç ve yöntem: Karabük ve komşu illerini kapsayan Batı Karadeniz bölgesinde yaşayan, Ocak-Aralık 2018 tarihleri arasında herhangi bir nedenle Karabük Eğitim Araştırma Hastanesi'ne başvuran 1-18 yaş arası 25(OH) D vitamini ölçülen çocuklar çalışmaya alındı. Çocuklar bölgesel olarak yaşa, cinsiyete ve mevsimsel başvuru zamanına göre gruplara ayrılarak serum $25(\mathrm{OH}) \mathrm{D}$ vitamin düzeyleri retrospektif olarak incelendi.

Bulgular: Çalışmaya 381'u kız (\%53,7), 328'i erkek (\%46,3) toplam 709 çocuk dahil edildi. Olguların ortalama serum $25(\mathrm{OH}) \mathrm{D}$ vitamin düzeyleri $18,8 \mathrm{ng} / \mathrm{mL}$ olup yaş gruplarına (1-4 yaş, 5-9 yaş, 10-14 yaş, 15-18 yaş) ve mevsimlere göre farklılıklar gösterdiği ortaya konmakla beraber yerleşim yerine göre farklılık saptanmadı. Erkeklerde ortalama serum $25(\mathrm{OH})$ D vitamin düzeyi $20,2 \mathrm{ng} / \mathrm{mL}$, kızlarda $17,3 \mathrm{ng} / \mathrm{mL}$ olup kızlarla erkekler arasında anlamlı fark olduğu tespit edildi $(p<0,001)$. Olguların $\% 12,8$ 'inde vitamin $D$ düzeyleri tam eksik, $\% 68,7$ 'ünde kısmi eksik, \%18,5'inde ise normaldi. Paratiroid hormon düzeyi ile D vitamin düzeyi arasında hem mevsimsel hem de D vitamin seviyesine göre ters orantı olduğu saptandı.

Sonuç: Batı Karadeniz bölgesinde yaşayan çocukların büyük çoğunluğunda vitamin $D$ vitamin düzeyleri düşüktü. Çocukların vitamin $D$ düzeyleri, mevsimsel farklılık göstermesine rağmen yerleşim yerine göre farklılık olmadığı tespit edildi.
\end{abstract}

Anahtar kelimeler: Çocuk, D vitamini, Batı Karadeniz bölgesi, mevsim.

Doğan E, Sevinç N. Vitamin Türkiye'de Batı Karadeniz bölgesindeki çocukların D vitamini düzeyleri. Pam Tıp Derg 2021;14:1-10.

\begin{abstract}
Purpose: Vitamin D level varies personally according to the angle and duration of the sun's contact with the skin surface, the amount of nutrients taken, and the amount of oral intake. Besides nutritional habits, the location of settlements, their height from the sea and climate properties affect the serum $25(\mathrm{OH}) \mathrm{D}$ vitamin levels of individuals. In this study, it was aimed to determine the serum $25(\mathrm{OH}) \mathrm{D}$ vitamin levels of children in the Western Black Sea region.

Materials and methods: Children who were living in the Western Black Sea region covering Karabük and neighbouring provinces, who applied to Karabük education and research hospital for any reason between January-December 2018, were measured for $25(\mathrm{OH})$ vitamin D. The children were divided into groups according to age, gender and seasonal application time, and their serum $25(\mathrm{OH}) \mathrm{D}$ vitamin levels were analyzed retrospectively.

Results: A total of 709 children, 381 girls $(53,7 \%)$ and 328 boys $(46,3 \%)$, were included in the study. The mean serum $25(\mathrm{OH})$ vitamin $D$ levels of the cases were $18,8 \mathrm{ng} / \mathrm{mL}$, and it was found that there were differences according to age groups (1-4 years, 5-9 years, 10-14 years, 15-18 years) and seasons, but no difference was found according to the settlements. The mean serum $25(\mathrm{OH})$ vitamin $\mathrm{D}$ level in boys was $20.2 \mathrm{ng} / \mathrm{mL}$ and $17.3 \mathrm{ng} / \mathrm{mL}$ in girls and was found to be a significant difference between girls and boys $(p<0,001)$. Complete deficiency, partial deficiency and normal serum $25(\mathrm{OH})$ vitamin D levels of cases were $12,8 \%, 68,7 \%$ and $18,5 \%$ (respectively). It was found that there was an inverse proportion between parathyroid hormone level and vitamin $\mathrm{D}$ level according to both seasonal and vitamin D levels.

Conclusion: Vitamin D vitamin levels were low in the majority of children living in the Western Black Sea region. Although Vitamin D levels of children differed seasonally but there was no difference according to the settlement.
\end{abstract}

Key words: Children, vitamin D, Western Black Sea region, seasons.

Dogan E, Sevinc N. Vitamin D levels of children in Western Black Sea Region of Turkey. Pam Med J 2021;14:110.

Erkan Doğan, Dr. Öğr. Üye. Karabük Üniversitesi Tıp Fakültesi Çocuk Sağığı ve Hastalıkları Anabilim Dalı, Karabük, Türkiye, e-posta: drerkandogan@hotmail.com (orcid.org/0000 00031620 4123) (Sorumlu Yazar)

Nergiz Sevinç, Dr. Öğr. Üye. Karabük Üniversitesi Tıp Fakültesi Halk Sağlığı Anabilim Dalı, Karabük, Türkiye, e-posta: dr.nergizsevinc@gmail. com (orcid.org/0000 00020257 4900) 


\section{Giriş}

D vitamini iskelet yapısının sağlıklı gelişmesi ve büyümesi için kalsiyum ve fosfor metabolizmasını düzenlemede önemli rol oynayan bir vitamindir. Kalsiferol olarak da bilinen $\mathrm{D}$ vitamininin, ekzojen olarak diyetle alınan ergokalsiferol (D2) ve güneş ışığının (ultraviyole) etkisi ile deride sentezlenen ve D vitamininin ana kaynağı olan kolekalsiferol (D3) olmak üzere iki farklı formu bulunur [1, 2]. D vitamininin en önemli etkisi kemik doku üzerine olmasının yanında çeşitli dokularda $D$ vitamini bağlayan reseptörlerin saptanmasıyla birçok sistemden kaynaklı farklı hastalıkların patogenezinde rol oynadığı bildirilmiştir. Bunun sonucu olarak D vitamin yetersizliği, sadece kemik dokuda mineralizasyon bozukluğu yaparak osteomalazi ve raşitizm gelişimine neden olmakla birlikte obezite, diyabetes mellitus, kardiyovasküler hastalıklar, kanser gibi birçok hastalığın riskini ve şiddetini artırmasından sorumlu tutulmuştur [3, 4]. Rutinde serum vitamin seviyesinin ölçülmesi ile D vitamini eksikliği kolaylıkla gösterilebilir. Vücudun $D$ vitamini ihtiyacı yaş ve cinse göre yaşam boyunca değişiklikler gösterdiğinden $25(\mathrm{OH})$ D vitamini düzeyine göre referans aralıkları erişkin yaş grubunda; <10 ng/mL (50 $\mathrm{nmol} / \mathrm{L})$ eksiklik, $10-30 \mathrm{ng} / \mathrm{mL}(50-75 \mathrm{nmol} / \mathrm{L})$ arası yetersizlik, $>30 \mathrm{ng} / \mathrm{mL}(75 \mathrm{nmol} / \mathrm{L})$ 'nin üzeri yeterli, çocukluk yaş grubunda ise $<12$ $\mathrm{ng} / \mathrm{mL}$ (30 nmol/L) eksiklik, 12-20 ng/mL (30-50 $\mathrm{nmol} / \mathrm{L}$ ) arası yetersizlik, >20 ng/mL (50 nmol/L) yeterli düzey olarak belirlenmiştir [5].

Son zamanlarda dünya genelinde $D$ vitamini eksikliği hem pandemik bir hastalık olarak kabul edilmekte hem de önemli bir halk sağlığı problemi olarak görülmektedir [6]. Bu durum sadece gelişmiş değil aynı zamanda gelişmekte olan ülkelerde de önemli bir sağlık problemine dönüşmüştür [7]. Ülkemizde çocuklarda D vitamin yetersizliği prevalansı tam olarak bilinmemektedir. Ülkemizin farklı coğrafi bölgelerinde farklı yaş gruplarını içeren D vitamini ile ilgili çalışmalar bulunmasına rağmen ilimizin de içinde bulunduğu Batı Karadeniz Bölgesindeki çocukların D vitamin düzeyleri üzerine yapılmış bir çalışma bulunmamaktadır. $\mathrm{Bu}$ çalışmada ilimizin de içinde olduğu Batı Karadeniz Bölgesinde yaşayan çocuklardaki D vitamini düzeylerini belirlemeyi amaçladık.

\section{Gereç ve yöntem}

Bu çalışmaya Karabük Üniversitesi Eğitim ve Araştırma Hastanesi'ne, Ocak-Aralık 2018 tarihleri arasında geriye dönük olarak bir yıllık süreçte herhangi bir nedenle çocuk polikliniklerine başvurmuş ve $25(\mathrm{OH}) \mathrm{D}$ vitamin düzeyleri ölçülen 1-18 yaş arası çocuklar dahil edildi. Kronik ve/veya otoimmun hastalığı olanlar ile metabolik hastalık veya hormon bozukluğu olanlar bu çalışmaya dahil edilmedi. Çalışmaya alınan çocuklar serum 25(OH) D vitamin düzeylerine, yaşlarına, cinsiyetlerine ve başvuru yaptığı aylar göre mevsimsel olarak gruplara ayrıldı. Belirlenen süre içinde birden fazla $25(\mathrm{OH}) \mathrm{D}$ vitamin düzeyi çalışılmış hastaların ilk ölçülen değeri çalışmaya dahil edildi. Serum 25(OH) D vitamin düzeyi Siemens ADVIA Centaur XP cihazında immunassay yöntemi ile ölçüldü. Bizim çalışmamızda serum $25(\mathrm{OH}) \mathrm{D}$ vitamin düzeyi $10 \mathrm{ng} / \mathrm{mL}$ 'nin altındaki değerler eksiklik, $10-30 \mathrm{ng} / \mathrm{mL}$ arasında olan değerler yetersizlik, $30 \mathrm{ng} / \mathrm{mL}$ 'nin üzerinde ölçülen değerler normal olarak kabul edildi. Etik onay; bu çalışma Karabük Üniversitesi Girişimsel Olmayan Etik Kurulu'nun 08/12/2019 tarih ve 2019/101 sayılı onayı ile Helsinki bildirgesine uygun olarak yapıldı.

\section{İstatistiksel analiz}

İstatistiksel analizlerde sonuçlar, ortalamalar \pm SD veya medyan (min-maks) olarak ifade edildi. Verilerin normal dağılıma uygunluğu Kolmogorov-Simirnov testi ile değerlendirildi. Anormal dağılım gösteren yaş, boy, kilo, 25(OH) D vitamin, alkalen fosfotaz, paratiroid hormon'a ait verilerin karşılaştırılması Mann-Whitney $U$ testi ile, normal dağılım gösteren vücut kitle indeksi, kalsiyum ve fosfor'a ait veriler student t-testi kullanılarak karşılaştırıldı. Korelasyon analizleri normal dağılım gösteren veriler pearson ile normal dağılım göstermeyen veriler spearman korelasyon analizi ile değerlendirildi. İstatistiksel analizler SPSS for Windows 21 paket programı kullanılarak yapıldı. $P$ değeri < 0,05 istatistiksel olarak anlamlı kabul edildi.

\section{Bulgular}

Araştırmaya alınan 709 olgunun 381'u kız $(\% 53,7), 328$ 'i erkek $(\% 46,3)$ olup, yaşları 1-18 (median yaş; 7) yıl arasında değişmekteydi. Olgularımızda kız çocukların erkek çocuklara göre oranı daha fazla olup, aradaki fark istatistiksel olarak anlamlı değildi $(p>0,05)$. 
Ortalama serum $25(\mathrm{OH})$ D vitamini düzeyleri 18,8 (4,0-86,6) ng/mL, erkeklerde 20,2 (4-86,6) $\mathrm{ng} / \mathrm{mL}$, kızlarda $17,3(4,2-85,2) \mathrm{ng} / \mathrm{mL}$ olarak bulundu. Ortalama serum $25(\mathrm{OH})$ D vitamini düzeyleri açısından kızlarla erkekler arasında istatistiksel olarak anlamlı fark bulundu $(p<0,001)$. Çalışmaya dahil edilen olguların temel demografik özellikleri ve serum $25(\mathrm{OH}) \mathrm{D}$ vitamini düzeyleri Tablo 1'de gösterildi.

Tablo 1. Olguların temel demografik özellikleri ve laboratuvar verileri

\begin{tabular}{llll}
\hline & KIZ & ERKEK & $p$ \\
\hline YAŞ (yıl) (min-maks) & $9(1-18)$ & $6(1-18)$ & NS \\
CiNSiYET & $381(\% 53,7)$ & $328(\% 46,3)$ & NS \\
BOY (cm) (min-maks) & $129(70-174)$ & $115(70-185)$ & $>0,005$ \\
KILO (kg) (min-maks) & $27(8-98)$ & $20,5(8,5-91)$ & 0,003 \\
25(OH) D vitamin (ng/mL) (min-maks) & $17,3(4,2-85,2)$ & $20,2(4-86,6)$ & 0,001 \\
Vücut Kitle İndeksi (VKI)*(SD) & $17,9 \pm 3,8$ & $16,9 \pm 1,8$ & 0,601 \\
Kalsiyum (mg/dL) (SD) & $9,7 \pm 0,4$ & $9,8 \pm 0,4$ & 0,678 \\
Fosfor (mg/dL) (SD) & $4,9 \pm 0,7$ & $5,2 \pm 0,7$ & 0,546 \\
Alkalen Fosfotaz (IU/L) (min-maks) & $172(41-493)$ & $196(69-486)$ & 0,701 \\
PTH (pg/mL) (min-maks) & $44,2(10,2-124,6)$ & $39,6(10,4-164)$ & 0,522 \\
\hline
\end{tabular}

*3 yaş üstü çocuklar için hesaplanmıştır. PTH: Paratiroid hormon, NS: Non significant

Çalışmaya dahil edilen olguların yaş gruplarına, cinsiyet ve mevsimsel dağılımları benzer olup istatistiksel olarak anlamlı fark saptanmadı. Tablo 2'de çalışmaya dahil edilen çocukların yaş gruplarına göre cinsiyet ve mevsimsel dağılımları gösterildi.

Çalışmaya alınan 1-4 yaş aralığındaki olguların serum $25(\mathrm{OH})$ D vitamin ortalama değeri 23,6 $(4,2-86,6) \mathrm{ng} / \mathrm{mL}, 5-9$ yaş aralığında $18,4(4,2-72,8) \mathrm{ng} / \mathrm{mL}, 10-14$ yaş aralığında $16,4(4,2-63,6) \mathrm{ng} / \mathrm{mL}, 15-18$ yaş aralığında ise $15,3(4,0-78,3) \mathrm{ng} / \mathrm{mL}$ idi, gruplar arasındaki fark anlamlıydı $(p<0,001)$. Ayrıca küçük yaş gruplarından büyük yaş gruplarına doğru ortalama serum $25(\mathrm{OH})$ D vitamin düzeylerinin azaldığı saptandı.

Tablo 2. Olguların yaş gruplarına ve mevsime göre dağılımı

\begin{tabular}{|c|c|c|c|c|c|c|c|}
\hline \multirow[t]{4}{*}{$\begin{array}{l}\text { YAŞ } \\
\text { GRUBLARI } \\
\text { (yaş) }\end{array}$} & & n (\%) & $(1-4)[n(\%)]$ & $(5-9)[n(\%)]$ & $(10-14)[n(\%)]$ & $(15-18)[n(\%)]$ & $p<0,469$ \\
\hline & $\mathrm{KIZ}$ & $381(\% 53,7)$ & $106(\% 45,7)$ & $87(\% 46)$ & $94(\% 55,6)$ & $94(\% 79)$ & \\
\hline & ERKEK & $328(\% 46,3)$ & $126(\% 54,3)$ & $102(\% 54)$ & $75(\% 44,4)$ & $25(\% 21)$ & \\
\hline & & & $232(\% 32,7)$ & $189(\% 26,6)$ & $169(\% 23,8)$ & $119(\% 16,9)$ & \\
\hline \multirow[t]{2}{*}{ MEVSIM } & & $\mathrm{N}$ & KIŞ & İLKBAHAR & YAZ & SONBAHAR & \\
\hline & & 709 & $122(\% 17,3)$ & $220(\% 31)$ & $199(\% 28)$ & $168(\% 23,7)$ & $p<0,256$ \\
\hline
\end{tabular}

Olguların mevsimlere göre başvuruları karşılaştırıldığında ilkbahar ve yaz mevsimlerinde ortalama serum $25(\mathrm{OH})$ D vitamin düzeyleri birbirlerine yakın dağılım göstermekteydi. Mevsimler arasında ortalama serum $25(\mathrm{OH})$ D vitamin düzeyleri arasında istatistiksel olarak anlamlı fark saptandı $(p<0,001)$ (Tablo 3). Mevsimlere göre paratiroid hormon (PTH) değerleri ise kış mevsiminde
43,4 (11,8-94,7) pg/mL, ilkbaharda 38,6 (10,2164) $\mathrm{pg} / \mathrm{mL}$, yaz mevsiminde $40,2(14,2-129,5)$ $\mathrm{pg} / \mathrm{mL}$, sonbaharda ise $41,8(10,2-90,0) \mathrm{pg} /$ $\mathrm{mL}$ idi. Değerlendirmeye alınan tüm olguların \%12,8'inde vitamin D düzeyi <10 ng/mL'nin altında (tam eksiklik), \%68,7'ünde 10-30 ng/mL arasında (kısmi eksiklik), \%18,5'inde >30 ng/mL üzerinde (normal düzey) saptandı (Tablo 3). 


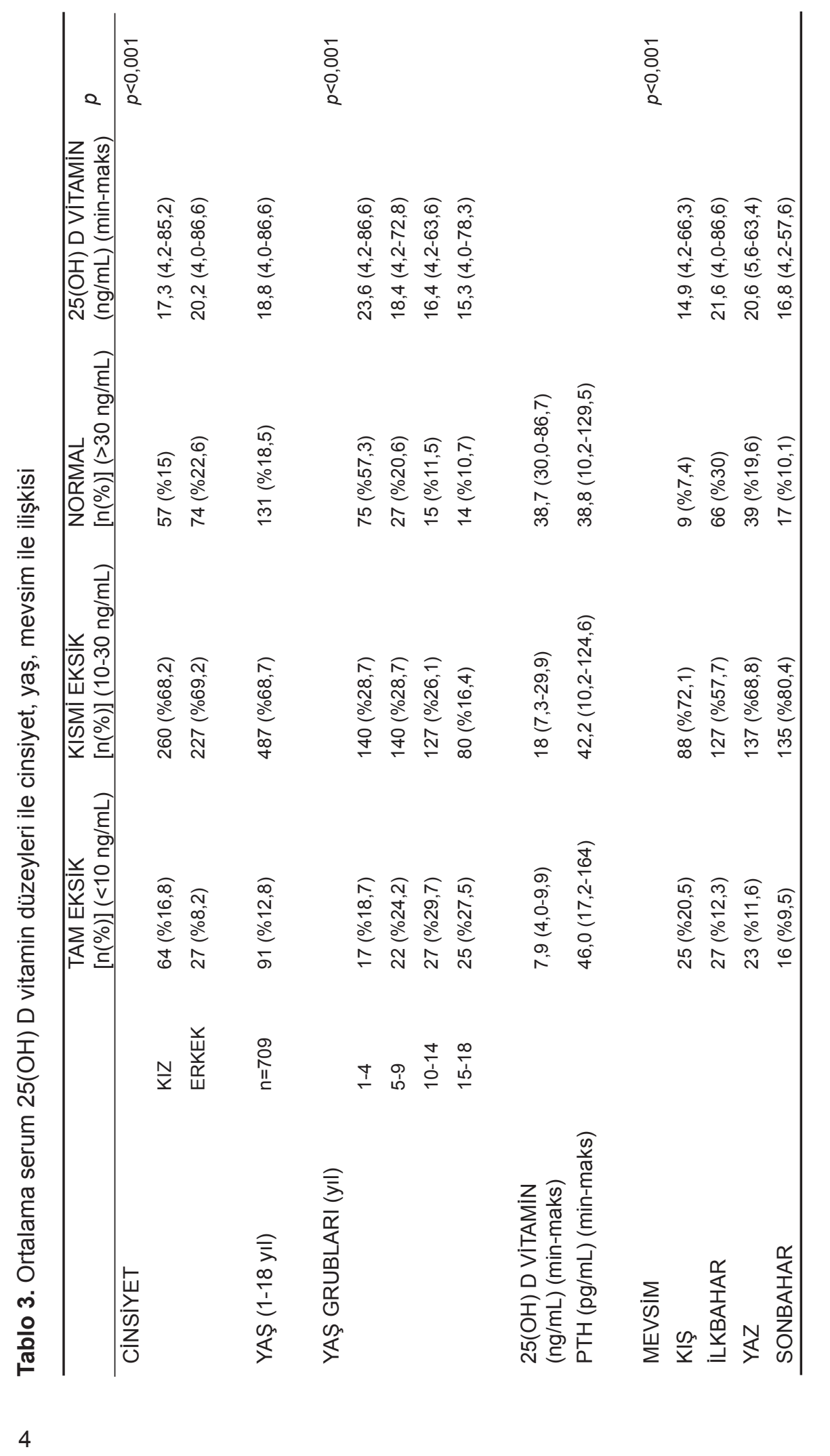


Yerleşim yerleri arasında olgu sayıları ile cinsiyet oranları ile yaş ortalamaları benzer dağılımda idi. Yerleşim yerlerine göre ortalama serum 25(OH) D vitamin düzeyleri arasında istatistiksel olarak anlamlı fark bulunmadı $(p=0,557)$. Olguların tüm yerleşim yerlerinde kısmi vitamin $D$ eksikliği oransal açıdan yüksek saptandı. Olgularda tam eksiklik (<10 ng/mL) oransal olarak \%17,3 ile en fazla Karabük, $\% 8,7$ ile en düşük Zonguldak ilinde, normal serum $25(\mathrm{OH})$ D vitamin düzeyleri $\% 25,3$ oranı ile en fazla Karabük, \%11,3 oranı ile en düşük Bartın ilinde saptandı. Değerlendirmeye alınan çocukların yerleşim yerlerine göre demografik dağılım ve $25(\mathrm{OH})$ D vitamin ortalama değerleri Tablo 4'de gösterildi.

\section{Tartışma}

Çalışmamızda hastaneye başvuran tüm olguların \%81,5'inde vitamin D yetersizliği/ eksikliği bulunarak prevalansın yüksek olduğunu saptandı. Batı Karadeniz Bölgesindeki 5 ili kapsayan çalışmamız vitamin D eksikliği ve/veya yetersizliğinin tüm mevsimlerde yüksek olduğunu (\%92,6 oranı ile en yüksek kış mevsiminde, $\% 70$ oranı ile en düşük ilkbahar) ortaya koydu. Tüm yaş gruplarında ortalama serum $25(\mathrm{OH}) \mathrm{D}$ vitamin düzeyi kızlarda $(17,3 \mathrm{ng} / \mathrm{mL})$ erkeklere göre (\%20,2 ng/mL) daha düşük olduğu bulundu. Ayrıca yaş ile ortalama serum $25(\mathrm{OH})$ D vitamin düzeyi arasında negatif korelasyon olduğu, erken yaş gruplarına göre (1-4 yaş arası 23,6 ng/ $\mathrm{mL}$ ) adolesan yaş gruplarında (15-18 yaş arası $15,3 \mathrm{ng} / \mathrm{mL}$ ) daha düşük olduğu gösterildi.

D vitamin eksikliği veya yetersizliği dünya çapında çok sık görülen önemli bir halk sağlığı problemi olup pandemik bir hastalık olarak kabul edilmekte ve prevalansı \%3060 arasında değişmektedir [6-8]. Kramer ve ark.'nın [9] Almanya'da yaptıkları çalışmada cinsiyet farkı olmadan, aylara göre farklılık göstermekle beraber tüm yaş gruplarında D vitamininin yetersizliği olduğunu saptadılar. Van der Meer ve ark.'nın [10] Avrupa'da yerleşimli diğer ülke göçmenleri ve Türk'lerde bölgelere göre değişmekle beraber \%29-90 arasında değişen yüksek oranda $D$ vitamin yetersizliğinin olduğunu buldular [11-14]. Türkiye, vitamin D eksikliğinin endemik olduğu ülkeler arasındadır [15]. Alpdemir M ve Alpdemir MF [16] 2000-2017 yıllarını kapsayan meta analizinde Türkiye'de D vitamin eksikliği oranının yaş, cinsiyet, mevsim, sosyoekonomik durum gibi nedenlerle bağlı olarak değişmekle beraber genel popülasyon da $\% 63$, infantlarda $\% 86,6$, çocuklarda $\% 39,8$ olduğunu bildirdiler. Topal ve ark.'nın [17] Erzincan bölgesindeki çocuklarda yaptıkları 2013-2016 yıllarını kapsayan çalışmada \%69,5, Özhan ve ark.'nın [18] Denizli Bölgesinde yaptıkları 2013 yılını kapsayan çalışmada $\% 63,5$, Meral ve ark.'nın [19] ise İstanbul bölgesinde yaptıkları 2013 yılını kapsayan çalışmalarında çocuklarda $\% 71,5$ oranında D vitamini düzeyinde eksiklik ve yetersizlik olduğunu bildirdi. Solak ve ark.'nın [20] Konya merkezli yaptıkları 2016 yılını kapsayan çalışmada 1-18 yaş tüm olguların ortalama $25(\mathrm{OH})$ D vitamin düzeyinin $17,1 \mathrm{ng} / \mathrm{mL}$ olduğunu, 1-18 yaş arasında \%94,5 oranında D vitamininde yetersizlik olduğunu bildirdiler. Biz çalışmamızda olguların \%81,5'unda serum $25(\mathrm{OH})$ D vitamin düzeylerinin eksik veya yetersiz olduğunu tespit ettik. Sonuçlarımız, Topal ve ark.'nın [17], Özhan ve ark.'nın [18] ile Meral ve ark.'nın [19] verilere göre daha yüksek, Solak ve ark.'nın [20] bildirdikleri orana göre daha düşük seviyede idi. Yaptığımız araştırmada elde ettiğimiz sonuçlar; mevsimsel ve bölgesel farklılıklar göstermekle beraber Türkiye'de farklı coğrafik bölgelerdeki ve Avrupa ülkelerinde yapılan çalışmalarla beraber değerlendirildiğinde genel olarak vitamin D eksiklik ve/veya yetersizlik oranındaki yüksekliğin Batı Karadeniz Bölgesi'ni kapsayan illerde de olduğunu ortaya koydu.

Yenidoğan döneminden itibaren tüm yaş gruplarında vitamin $D$ eksikliği ve yetersizliğinin pek çok sağlık problemine zemin hazırladığı ve ilişkili olduğu bildirilmiştir [21, 22]. Katrinaki ve ark.'nın [23] Yunanistan'da yaptıkları kohort çalışmasında çocuk ve adolesan dönemde (020 yaş) ortalama $25(\mathrm{OH}) \mathrm{D}$ vitamin düzeyinin hem kızlarda $(23,1 \mathrm{ng} / \mathrm{mL})$ hem de erkeklerde $(24,2 \mathrm{ng} / \mathrm{mL})$ diğer yaş gruplarına göre daha yüksek olduğunu, yaş ilerledikçe yaş gruplarında D vitamin düzeyinin azaldığını bildirdiler. Solak ve ark.'nın [20] Konya merkezli yaptıkları çalışmada ortalama serum $25(\mathrm{OH})$ D vitamin düzeyini kızlarda 15,1 ng/mL, erkeklerde 20,6 ng/mL, Meral ve ark.'nın [19] İstanbul bölgesinde yaptıkları çalışmada kızlarda 20,4 ng/mL, erkeklerde 22,5 ng/mL, Topal ve ark.'nın [17] ise Erzincan bölgesinde yaptıkları çalışmada kızlarda 17,9 ng/mL, erkeklerde \%19,9 ng/ $\mathrm{mL}$ olduğunu bildirdiler. Yaptığımız çalışmada kızlarda bulduğumuz sonuç (17,3 ng/mL) Topal ve ark.'nın [17] sonuçları ile erkeklerde bulduğumuz sonuç $(20,2 \mathrm{ng} / \mathrm{mL})$ ise Solak ve ark. [20] ve 


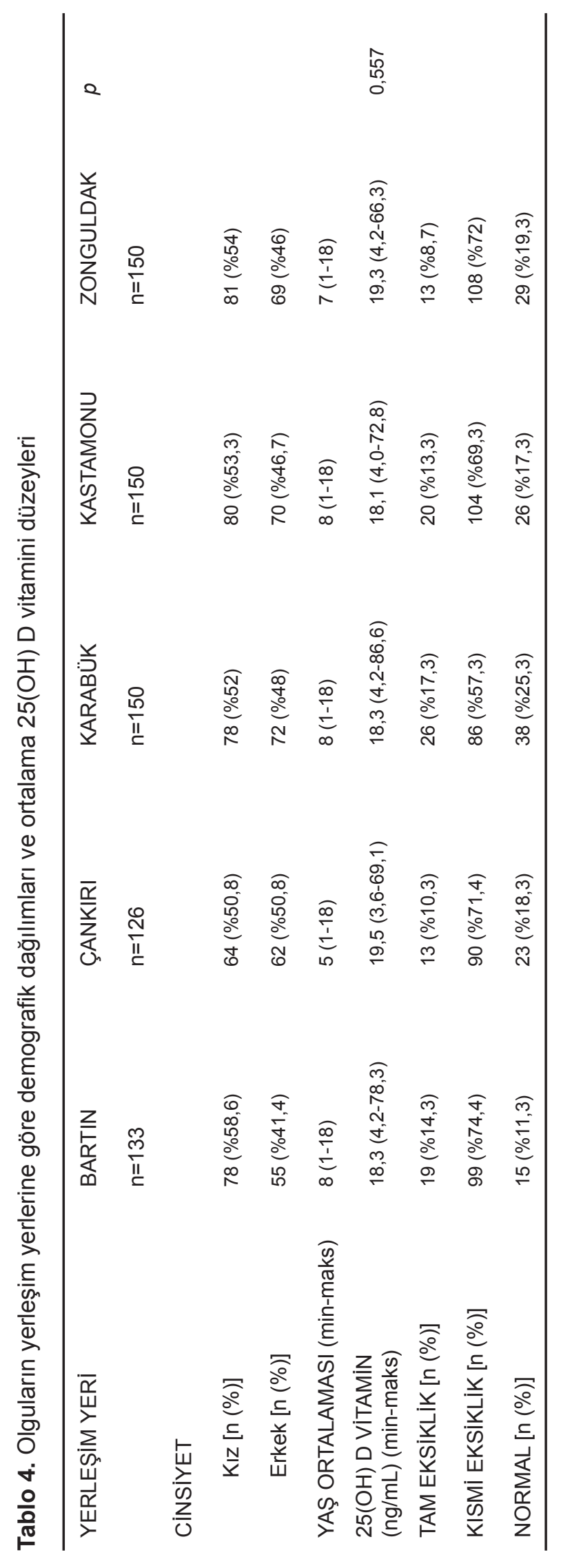


Topal ve ark.'nın [17] bildirdikleri sonuçlara benzerdi. Farklı bölgelerden yapılan çalışmalar değerlendirildiğinde tüm çalışmalarda $\mathrm{D}$ vitamin düzeyinin kızlarda erkeklere oranla genel olarak daha düşük olduğu görülmektedir.

Yaş gruplarına göre; Meral ve ark.'nın [19] yaptıkları çalışmada 0-5 yaş, 6-10 yaş ve 1120 yaş gruplarında ortalama serum $25(\mathrm{OH}) \mathrm{D}$ vitamin düzeylerini $30,2 \pm 22,1 \mathrm{ng} / \mathrm{mL}, 20,1 \pm 10,2$ $\mathrm{ng} / \mathrm{mL}$ ve $17,6 \pm 16,9 \mathrm{ng} / \mathrm{mL}$ olarak bulduklarını ve yaş gruplarında sırasıyla $\% 4,3, \% 72, \% 84,4$ oranında vitamin $D$ eksiklik ve/veya yetersizliğin olduğunu bildirdiler. Çalışmamızdaki veriler Meral ve ark.'nın [19] yaptıkları çalışma ile kıyaslandığında bütün yaş gruplarında ortalama serum $25(\mathrm{OH})$ D vitamin düzeyleri daha düşüktü. Gerek bizim çalışmamız gerekse Meral ve ark.'nın [19] yaptığı çalışmada benzer olarak yaş arttıkça $D$ vitamin düzeyinin azaldığı bulundu.

Serum 25(OH) D vitamin düzeyi; coğrafik olarak bölgenin konumu, iklimsel durumu, güneş ışığına maruz kalma süresi ile beslenme, yaşam ve giyim şekli gibi birçok nedenden etkilenmekte ve yetersizlik gelişmesine zemin hazırlamaktadır [6, 24]. Çocuklardaki büyümenin ve fiziksel gelişimin hızlanması, kemik mineralizasyonunun artması nedeniyle serum $25(\mathrm{OH})$ D vitamini ihtiyacı ve tüketimi artmakta, dolayısı ile laboratuvar sonucu olarak serum $25(\mathrm{OH})$ D vitamin düzeyinde düşme sonucu ile karşılaşmamıza neden olabilmektedir $[9,25]$.

Adolesan yaşlar çocukların iskelet gelişiminin en kritik olduğu dönemdir. Puberte, boy büyümesi ve fiziki gelişimin hızlı artması nedeniyle fizyolojik olarak kalsiyum ve $D$ vitamin ihtiyacının en fazla olduğu bir dönemdir. Kramer ve ark. [9] Almanya'da 2008-2011 yıllarını kapsayan 98.000 olgunun dahil edildiği çalışmalarında adolesanlarda $D$ vitamin düzeylerinin düşük olduğunu bildirdiler. 2014 yılında Ashraf T Soliman ve ark.'nın [25] yaptıkları çalışmada, Kramer ve ark.'nın [9] bildirdikleri sonuçlara benzer şekilde adolesan yaş grubunda $D$ vitamini eksikliğinin daha fazla olduğunu bildirdiler. Ülkemizden ise adolesan yaş grubunda D vitamin düzeyini bildiren çalışmalarda; Topal ve ark. [17], Erzincan bölgesinde yaptıkları çalışmada yaş ilerledikçe $\mathrm{D}$ vitamin düzeylerinin azaldığını, erken adolesan dönemde ortalama serum $25(\mathrm{OH})$ D vitamin düzeyinin $(13,4 \mathrm{ng} / \mathrm{mL})$ en düşük olduğunu bildirdiler. Meral ve ark.'nda [19] yaptıkları çalışmada ortalama serum $25(\mathrm{OH})$ D vitamin düzeylerini $11-20$ yaş arası $17,6 \mathrm{ng} / \mathrm{mL}$ değeri ile adolesan dönemde diğer yaş gruplarına göre $D$ vitamin düzeyinin en düşük olduğunu bildirdiler. Çalışmamızda bulduğumuz sonuçlar hem Topal ve ark. hem de Meral ve ark.'nın sonuçlarıyla benzer şekilde ortalama serum $25(\mathrm{OH}) \mathrm{D}$ vitamin düzeyi en düşük adolesan yaş grubundaydı. Bu durumun muhtemel sebebinin adolesan dönemde büyümenin ve gelişmenin hızlı artmasıyla beraber $D$ vitaminine fizyolojik gereksinimin daha da artmasından kaynaklandığı düşünülebilir ve bu nedenle $D$ vitamin eksikliği gelişmesine veya var olan eksikliğin derinleşmesine sebep olabilir [25].

Güneş ışınlarının kış mevsimi boyunca yetersizliğiyle birlikte ışınların temas açısının değişlik göstermesi ve dolayısı ile cilde temas sıklığı ve miktarının azalması, deri yolu ile fizyolojik vitamin D oluşmasını azaltır. Santos ve ark. [24] Portekiz'de yaptıkları çalışmada ortalama serum $25(\mathrm{OH})$ D vitamin düzeyinin mevsimlere göre önemli farklılıklar gösterdiğini, en yüksek yaz mevsiminde, en düşük ise kış mevsiminde bulduklarını bildirdiler. Meral ve ark.'nın [19] yaptıkları çalışmada ortalama serum $25(\mathrm{OH})$ D vitamin düzeyini en düşük yaz mevsiminde $(19,0 \mathrm{ng} / \mathrm{mL})$, en yüksek sonbahar mevsiminde $(26,8 \mathrm{ng} / \mathrm{mL})$, Solak ve ark.'nın [20] yaptıkları çalışmada ise en düşük kış mevsiminde (Ocak ayında 12,9 ng/mL), en yüksek yaz mevsiminde (Ağustos ayında 17,8 $\mathrm{ng} / \mathrm{mL}$ ) bulduklarını bildirdiler. Çalışmamızda, ortalama $25(\mathrm{OH})$ D vitamin düzeyi tüm mevsimlerde düşük olmakla beraber diğer çalışmalardan farklı olarak en yüksek ilkbahar mevsiminde, en düşük ise diğer çalışmalara benzer şekilde kış mevsiminde olduğunu saptadık. D vitamin seviyelerindeki farklılıkların sebebi; çoğrafi konum, deniz seviyesinden itibarenki yükseklik, yıllara göre bölgesel mevsimsel yağış miktarlarındaki farklılıklar bağlı olarak güneşe maruz kalma süresindeki değişiklikler $\mathrm{D}$ vitaminindeki düşüklüğü açıklayabilir.

Cinsiyetler arasında vitamin D düzeyindeki farklılıkların nedeni; cinsiyete bağlı olarak fiziksel gelişim de etkin rol oynayan hormonların etkisi yanında, erkeklere göre kızlarda vücut kitle indeksi (VKI)'nin daha yüksek olması, kilo 
arttıkça vitamin D'nin yağ dokusunda birikerek serum $25(\mathrm{OH})$ D vitamin seviyesinin düşmesine neden olduğu bildirilmiştir. Shim ve ark.'nın [26] Kore'de 2015-2018 yılları arasında 6-18 yaş arası 822 olgunun dahil edildiği çalışmalarında serum 25(OH) D vitamin düzeyi ile VKİ arasında zayıf negatif korelasyon olduğunu, VKI arttıkça serum $25(\mathrm{OH})$ D vitamin düzeyinin azaldığını buldular. Hollanda'da 2012-2013 yılları arasında 6-18 yaş arası çocukların dahil edildiği Radhakishun ve ark.'nın [27] yaptıkları bir çalışmada da Shim ve ark.'nın [26] sonuçlarına benzer sonuç bildirdiler. Türkiye'den yapılan; Atasoy ve ark.'nın [28] Trabzon'da Aralık 2015-Aralık 2016 tarihleri arasında 6-18 yaş arası kilo fazlalığı veya obezite tanısı ile takipli olguların dahil edildiği çalışmada $D$ vitamini düzeyi ile VKİ arasında ilişki saptamadılar. Diğer bir çalışmada ise Çakıl [29] obez çocuklarda serum $25(\mathrm{OH})$ D vitamin düzeyi ile VKI arasında negatif yönde korelasyon saptadı. Yaptığımız çalışmada Atasoy ve ark.'ndan [28] farklı olarak VKİ ile serum 25(OH) D vitamin düzeyi arasında zayıf negatif korelasyon saptadık. Çalışmamızın sonuçları Shim ve ark. [26], Radhakishun ve ark. [27] ile Çakıl'ın [29] sonuçlarına benzerdi. Çalışmamızın Atasoy ve ark.'nın [28] çalışmaları ile uyumlu olmamasının muhtemel sebebi; Atasoy'un yaptığı çalışmada dahil edilen olguların tamamı fazla kilolu (\%87'si obez, \%13'ü ise fazla kilolu) olgulardan oluşmaktadır. Bizim çalışmamızda ise erkeklerin VKl'i 16,9 kg/ $\mathrm{m}^{2}$, kızların $17,9 \mathrm{~kg} / \mathrm{m}^{2}$ idi.

Serum 25(OH) D vitamin düzeyi, paratirod hormon (PTH)'nun serum düzeyinin belirlenmesinde önemli rol oynar. Kroll ve ark.'nın [30] 2015 yılında ABD'de yaptıkları bir çalışmada serum $25(\mathrm{OH})$ D vitamin düzeyleri ile PTH arasında coğrafi bölgelere, mevsimlere ve cinsiyete göre periyodik değişim gösterdiğini, 25(OH) D vitamin düzeyi ile PTH'un ters orantılı olduğunu, vitamin $D$ düzeyi ne kadar düşük ise PTH seviyesinin o kadar yüksek, vitamin $D$ değerinin en düşük olduğu aylarda PTH düzeyinin en yüksek olduğunu bildirdiler. Ülkemizden Karagülmez ve ark. [31] Trabzon bölgesinde yaptıkları ilkbahar ve sonbahar mevsimlerini kapsayan çalışmalarında ilkbaharda serum $25(\mathrm{OH})$ D vitamin düzeyini $27,8 \pm 14 \mathrm{nmol} / \mathrm{L}$, sonbaharda 40,8 $\pm 19,8 \mathrm{nmol} / \mathrm{L}$, PTH düzeyleri ise ilkbaharda $60,9 \pm 45,0 \mathrm{pg} / \mathrm{mL}$, sonbaharda ise $42,2 \pm 23,1 \mathrm{pg} / \mathrm{mL}$ bulduklarını, serum $25(\mathrm{OH})$ D vitamin düzeyleri ile $\mathrm{PTH}$ arasında ters orantılı olduğunu, mevsime göre de değişim gösterdiğini bildirdiler. Her iki çalışmanın sonuçlarıyla uyumlu olarak bu araştırmamız D vitamin düzeylerinin mevsimsel değişiklik gösterdiğini ortaya koydu. Denizli'den Kocamaz'ın [32] 2015-2016'da 1 ay-18 yaş arası 294 çocukta D vitamin eksikliği (<12 ng/ $\mathrm{mL})$, yetersizliği $(12-20 \mathrm{ng} / \mathrm{mL})$ ve normal (>20 ng/mL) olan olgularda PTH düzeylerini sırası ile 32,9 (21,1-61,7) pg/mL, 31,5 (11,2$57,5) \mathrm{pg} / \mathrm{mL}$ ve $31,4(7,16-65) \mathrm{pg} / \mathrm{mL}$ olarak bulduğunu, aralarında istatistiksel olarak anlamlı farkın olmadığını bildirdi $(p<0,878)$. Çalışmamızda ise PTH'u, D vitamin seviyesine göre karşılaştırdığımızda serum $D$ vitamin ile PTH arasında ters orantı olduğunu tespit ettik. Serum 25(OH) D vitamin düzeyi ile PTH karşılaştırılmasında $D$ vitamin düzeyinin en düşük olduğu mevsimde $\mathrm{PTH}$ düzeyinin en yüksek olduğunu, aralarında ters orantının olduğunu ortaya koydu.

Çalışmamızı sınırlayan; retrospektif bir çalışma olması nedeniyle çalışmaya dahil edilen olguların yaşam koşulları, beslenme durumları, şikayetleri, olguların güneşe temas süreleri yanında cilt renginin esmer olup olmadığının bilinememesi, takviye amaçlı D vitamini alıp almadıkları bilgilerinin elde edilememesidir.

$\mathrm{Bu}$ çalışma, ilimizin de bulunduğu Batı Karadeniz Bölgesi'nde her yaş grubunda özellikle de çocuklarda serum $25(\mathrm{OH})$ D vitamin düzeyi genel olarak düşüklüğünü ortaya koyması yanında yaş ilerledikçe (özellikle adolesan yaş grubunda) ortalama serum $25(\mathrm{OH})$ D vitamin düzeyi daha da azaldığını, eksiklik ve/veya yetersizliğin daha da belirginleştiğini göstermiştir. D vitamininden zengin veya zenginleştirilmiş besinlerin tüketiminin arttırılması veya oral yolla $D$ vitamin destek tedavisi gerekliliğini göstermesi açısından çalışmamız önemli verileri ortaya koymuştur.

Çıkar ilişkisi: Yazarlar çıkar ilişkisi olmadığını beyan eder.

\section{Kaynaklar}

1. Holick MF. Vitamin D status: measurement, interpretation, and clinical application. Ann Epidemiol 2009;19:73-78. https://doi.org/10.1016/j. annepidem.2007.12.001

2. Kulie T, Groff A, Redmer J, Hounshell J, Schrager S. Vitamin D: an evidence-basedreview. J Am Board Fam Med 2009;22:698-706. https://doi.org/10.3122/ jabfm.2009.06.090037 
3. Holick MF, Binkley NC, Bischoff Ferrari HA, et al. Evaluation, treatment, and prevention of vitamin $D$ deficiency: an Endocrine Society clinical practice guideline. J Clin Endocrinol Metab 2011;96:1911-1930. https://doi.org/10.1210/jcem.96.12.zeg3908

4. Souberbielle JC, Body JJ, Lappe JM, et al. Vitamin D and musculoskeletal health, cardiovascular disease, autoimmunity and cancer: recommendations for clinical practice. Autoimmun Rev 2010;9:709-715. https://doi. org/10.1016/j.autrev.2010.06.009

5. Munns CF, Shaw N, Kiely M, et al. Global consensus recommendations on prevention and management of nutritional rickets. Horm Res Paediatr 2016;85:83-106. https://doi.org/10.1159/000443136

6. Holick MF, Chen TC. Vitamin D deficiency: a worldwide problem with health consequences. Am J Clin Nutr 2008;87:1080-1086. https://doi.org/10.1093/ ajcn/87.4.1080S

7. Arabi A, El Rassi R, Fuleihan GE. Hypovitaminosis D in developing countries prevalence, risk factors and outcomes. Nat Rev Endocrinol 2010;6:550-561. https:// doi.org/10.1038/nrendo.2010.146

8. Holick MF. The vitamin D deficiency pandemic: approaches for diagnosis, treatment and prevention. Rev in Endocr Metab Disord 2017;18:153-165. https:// doi.org/10.1007/s11154-017-9424-1

9. Kramer J, Diehl A, Lehnert H. Epidemiological study on the dimension of vitamin $D$ deficiency in North Germany. Dtsch Med Wochenschr 2014;139:470-475. https://doi.org/10.1055/s0033-1360073

10. Van der Meer IM, Middelkoop BJ, Boeke AJ, Lips PT. Prevalence of vitamin D deficiency among Turkish, Moroccan, Indian and sub-Sahara African populations in Europe and their countries of origin: an overview. Osteoporos Int 2011;22:1009-1021. https://doi. org/10.1007/s00198-010-1279-1

11. Moreno Reyes R, Carpentier $Y A$, Boelaert $M$, et al. Vitamin $D$ deficiency and hyperparathyroidism in relation to ethnicity: a cross-sectional survey in healthy adults. Eur J Nutr 2009;48:31-37. https://doi. org/10.1007/s00394-008-0756-1

12. Erkal MZ, Wilde J, Bilgin $Y$, et al. High prevalence of vitamin $D$ deficiency, secondary hyperparathyroidism and generalized bone pain in Turkish immigrants in Germany: identification of risk factors. Osteoporos Int 2006;17:1133-1140. https://doi.org/10.1007/s00198006-0069-2

13. Van der Meer IM, Karamali NS, Boeke AJ, et al. High prevalence of vitamin $\mathrm{D}$ deficiency in pregnant nonWestern women in The Hague, Netherlands. Am J Clin Nutr 2006;84:350-353. https://doi.org/10.1093/ ajcn/84.2.350
14. Holvik K, Meyer HE, Haug E, Brunvand L. Prevalence and predictors of vitamin $\mathrm{D}$ deficiency in five immigrant groups living in Oslo, Norway: the Oslo Immigrant Health Study Eur J Clin Nutr 2005;59:57-63. https://doi. org/10.1038/sj.ejcn.1602033

15. Satman I, Colak Ozbey N, Boztepe H, et al. Prevalence and of vitamin $\mathrm{D}$ deficiency and associated factors in Turkey. J Diabetes 2012;1:6.

16. Alpdemir M, Alpdemir MF. Meta analysis vitamin D deficiency status in Turkey: a meta-analysis. Int J Med Biochem 2019;2:118-131. https://doi.org/10.14744/ ijmb.2019.04127

17. Topal I, Mertoğlu C, Arslan YK, Gümüş A, Kara îs, Peker N. Erzincan bölgesindeki çocukların D vitamini seviyelerinin yaş, cinsiyet ve mevsimlere göre değerlendirilmesi. Fırat Tıp Dergisi 2018;23:168-172.

18. Ozhan B, Evrengul H, Agladıoglu SY, Yasar Ü, Demır S. Vitamin $D$ status of children in a university hospital in west Turkey. HK J Paediatr 2016;21:251-256.

19. Meral G, Guven A, Uslu A, et al. The prevalence of vitamin $D$ deficiency in children, adolescents and adults in a sample of Turkish population. Studies on Ethno-Medicine 2016;10:249-254. https://doi.org/10.1 080/09735070.2016.11905494

20. Solak I, Cihan FG, Mercan S, Kethuda T, Eryılmaz MA. Evaluation of 25-hydroxyvitamin D levels in Central Anatolia, Turkey. BioMed Research International 2018:4076548. https://doi.org/10.1155/2018/4076548

21. Özkan, B, Döneray, HD. D vitamininin iskelet sistemi dışı etkileri. Çocuk Sağlığı ve Hastalıkları Dergisi 2011;54:99-119.

22. Holick MF. Vitamin D: a D-Lightful health perspective. Nutr Rev 2008;66:182-194. https://doi.org/10.1111/ j.1753-4887.2008.00104.x

23. Katrinaki M, Kampa M, Margioris A, Castanas E, Malliaraki N. Vitamin D levels in a large Mediterranean cohort: reconsidering normal cut-off values. Hormones 2016;15:205-223. https://doi.org/10.14310/ horm.2002.1674

24. Santos MJ, Fernandes V, Garcia FM. Vitamin D insufficiency in a hospital population: a photograph from the laboratory perspective. Acta Med Port 2015;28:726-734.

25. Soliman AT, De Sanctis V, Elalaily R, Bedair S, Kassem I. Vitamin D deficiency in adolescents. Indian J Endocrinol Metab 2014;18:9-16. https://doi. org/10.4103/2230-8210.145043.

26. Shim KS, Cho JH, Jung HW. Relationship between 25-hydroxyvitamin $\mathrm{D}$ with adiposity assessed by body mass index, serum glucose and lipids levels in Korea: a cross-sectional analysis. In58th Annual European Society for Paediatric Endocrinology (ESPE) Meeting;Vienna, Austria, 2019;92:3-103. 
27. Radhakishun N, van Vliet M, von Rosenstiel I, et al. High prevalence of vitamin $D$ insufficiency/deficiency in Dutch multi-ethnic obese children. Eur J Pediatr 2015;174:183190. https://doi.org/10.1007/s00431-014-2378-3

28. Atasoy V, Altunbaş EA, Set T. Fazla kilolu ve obez çocuklarda $D$ vitamini düzeylerinin değerlendirilmesi. Türk Aile Hek Derg 2019;23:102-109. https://doi. org/10.15511/tahd.19.00302

29. Çakıl Sağlık A. Çocuklarda vücut kitle indeksi ile insülin direnci ve $D$ vitamini düzeyleri arasındaki ilişki. Yayımlanmamış Uzmanlık Tezi. Maltepe Üniversitesi, Tıp Fakültesi, İstanbul, 2013.

30. Kroll MH, Bi C, Garber CC, et al. Temporal relationship between vitamin $\mathrm{D}$ status and parathyroid hormone in the United States. PLoS One. 2015;10. 10.1371/journal. pone. 0118108

31. Karagüzel G, Dilber B, Çan G, Ökten A, Deger O, Holick MF. Seasonal vitamin D status of healthy schoolchildren and predictors of low vitamin D status. J Pediatr Gastroenterol Nutr 2014;58:654-660. https://doi. org/10.1097/MPG.0000000000000274

32. Kocamaz H. Çocukluk çağı gastrointestinal sistem hastalıklarında D vitamini düzeyleri. Ortadoğu Tıp Derg 2019;11:542-547. https://doi.org/10.21601/ ortadogutipdergisi.474979

Teşekkürler: Yazının her aşamasında katkı ve desteğini esirgemeyen Doç.Dr.Eylem Sevinç'e teşekkürlerimizi sunuyoruz

Etik onayı: Bu çalışma Karabük Üniversitesi Girişimsel Olmayan Etik Kurulu'nun 08/12/2019 tarih ve 2019/101 sayılı onayı ile yapılmıştır.

\section{Yazarların makaleye olan katkıları}

E.D. çalışmanın ana fikrini ve hipotezini kurgulamış/kurgulamışlardır. E.D., N.S., teoriyi geliştirmiş ve materyel metod bölümünü düzenlemişlerdir. Sonuçlar kısmınındaki verilerin değerlendirmesini E.D. ve N.S. yapmışlardır. Makalenin tartışma bölümü E.D. tarafından yazılmış, E.D. ve N.S. gözden geçirip gerekli düzeltmeleri yapmış ve onaylamıştır. Ayrıca tüm yazarlar çalışmanın tamamını tartışmış ve son halini onaylamıştır. 